\title{
The Role of Small and Medium Enterprises (SMEs) to Employment in Ghana
}

\author{
Seth Kwaku Amoah ${ }^{1, ~ *, ~ A l f r e d ~ K w a b e n a ~ A m o a h ~}{ }^{2}$ \\ ${ }^{1}$ Department of Procurement and Supply Chain Management, Faculty of Business and Management Studies, Sunyani Technical University, \\ Sunyani, Ghana \\ ${ }^{2}$ Ghana National Ambulance Service, Sunyani, Ghana
}

Email address:

sethamoah32@yahoo.com (S. K. Amoah), alfredkwabenaamoah@gmail.com (A. K. Amoah)

${ }^{*}$ Corresponding author

To cite this article:

Seth Kwaku Amoah, Alfred Kwabena Amoah. The Role of Small and Medium Enterprises (SMEs) to Employment in Ghana. International Journal of Business and Economics Research. Vol. 7, No. 5, 2018, pp. 151-157. doi: 10.11648/j.ijber.20180705.14

Received: August 10, 2018; Accepted: September 7, 2018; Published: October 11, 2018

\begin{abstract}
The study used descriptive statistics design type to assess the role that MSMEs are playing with respect to employment in Ghana. The study adopted the methodology employed by Ghana Statistical Service (GSS) to undertake a nationwide survey on the Integrated Business Establishment Survey II (IBES II, 2016). It used the data generated by GSS from IBES II 2016 Survey report. The data set used included the employment levels (numbers), size and the status of employment (permanent and temporary) offered by MSMEs in Ghana. It was revealed from the study that the MSMEs in Ghana offered employment of about 82 percent to the working population in the country with marked differences in the regions. Out of the employment offered by MSMEs in Ghana, about 81 percent is for permanent whilst 86 percent is for temporary employment. The Micro enterprises employed larger percentage of the working population than the Small and Medium enterprises. We are recommending that the central, regional and district structures of governance in the country should continue to initiate, develop and implement pragmatic policies that will enhance the growth of the MSMEs' sector in the country. The programmes and policies to enhance the growth of the Sector should be focused on specific areas and size of the MSMES. The MSMEs sector at all levels is still confronting with both endogenous and exogenous challenges such as access to funds, lack of managerial skills and applications of appropriate technologies, registration and regulations issues as well as record keeping and access to international market. All stakeholders in the sector should work hand in hand to resolve these challenges for optimum operation of the MSMEs in the country to help reduce the unemployment situation in the country.
\end{abstract}

Keywords: Status of Employment, Role, Small and Medium Enterprise (SMEs)

\section{Introduction}

Small and Medium Enterprises (SMEs) including Micro enterprises are playing critical roles for socio-economic development of nations especially in the areas of employment and job creation throughout the world. The SME sector is contributing immensely to economic growth, more importantly to employment and job creation in both developed and developing nations. In the case of developed and transitional economies, [1] concluded that, SMEs provided 60-70 percent of employment in those economies. In developing nations, $[2,3]$ were with the view that SMEs offered about 45 percent of total employment and 33 percent of Gross Domestic Product (GDP). The SMEs are often considered as engines for innovation, economic growth, employment and social mobility as cited by $[4,5]$. The jobs created and employments offered by the SMEs generally improve the welfare, standard of living, income levels and social stability of people across the world including African countries.

The SMEs in Africa are accounting for about 90 percent of all enterprises and can be found in most rural and urban areas in the sub-region. For example, in South Africa, the SMEs, contributes about 84 percent to private sector employment[6, 7] and in Kenya, the sector contributes immensely to the macroeconomic development of the economy by providing employment, training entrepreneurs, generating income and 
improving the living standard of most of the low income households in the country. Furthermore, the sector contributes about 71percent to employment and accounts for about 92 percent of businesses in Ghana respectively [8, 9]. The SMEs sector in Ghana also employed 85 percent of manufacturing labour force who are sparsely distributed across the regions including the rural and urban settlements in the country. This makes the SMEs sector the most important sector in the Ghanaian economy for policy makers, development practitioners and community leaders to continue to initiate, develop and direct pragmatic strategies to improve the sector. It is observed that, an improvement in the SME sector in Ghana will help to improve the unemployment conditions and the well-being of the people in the country.

The nature of the activities of the SMEs in Ghana is diverse and sparsely distributed across the regions including the rural areas. For instance, employment offered by the SMEs including Micro enterprises is dotted across the regions in the country. There are various studies in Ghana on SMEs in relation to economic growth and development, challenges facing the sector, the nature and dynamics of the SMEs sector and factors determining the location of SME firms in the nation [8, 10-12]. Few of these studies have considered the role of SMEs to employment at the national and regional levels [8, 10-12]. It is against this background that this present study wants to assess the role of SMEs including Micro enterprises to employment and job creation at the national and regional levels.

The main goal of the study is to assess the role of SMEs to employment in Ghana. It will specifically find out the levels of employment, the size and status of employment by SMEs at the national and regional levels and to review the challenges facing the SMEs sector as well as recommending areas of policy interventions to improve the Sector. Apart from this section, the rest of the study is organized into five sections. The section two reviews the related literature including the definition of SMEs and empirical studies on the role of SMEs to employment. The section three discusses the methodology of the study whilst section four presents the results and discussions of the study. The last section covers the conclusion and policy recommendations of the study.

\section{Literature Review}

\subsection{Definition of SME}

There is no definite definition for Small and Medium Enterprises (SMEs) including Micro firms that is accepted by the world. There are various forms of definitions of SMEs throughout the world. It differs from country to country as well as organization or industry to industry. Many countries or organizations define SME differently depending upon the purpose for defining it [13-16]. Other authors defined SME as the number of people employed, total assets of the establishment and sales turnover of the firm [8, 17, 18]. As cited by [8], the European Commission (EC) used the number of workers employed by a firm to define SME.
According to the EC's definition, firms with 0 to 9 employees are micro enterprises; 10 to 99 employees are small whilst firms with 100 to 499 employees are medium enterprises. The SME has definitional problem, hence each country or organization has its own definition to suit its needs and aspirations at any point in time.

\subsection{Definition of SME in Ghana}

In Ghana, most of the definitions on SMEs are based on the number of workers employed by the enterprises [10]. For instance, [19] used an employment cut-off point of 30 employees as small scale enterprises whilst [20] as cited by [8] used the number of workers a firm has employed over time to classify small-scale enterprises into three categories. They concluded that a firm employing less than 6 people is micro, employing between 6 to 9 people as very small and between 10 to 29 employees as small enterprise. Also, [19] used employment levels of the enterprises to classify SMEs in Ghana into micro enterprise (less than 5 employees); small enterprise (5 to 29 employees); medium enterprise (30 to 99 employees); large enterprise (100 and more employees).

Also, Ghana Statistical Service (GSS) has defined SME by using the number of employees a firm has employed at any point in time to classify a firm to be small and medium enterprises. According to GSS, SME is defined as any enterprise or business entity that employs between 1 to 5 as micro, a firm employing between 6 to 30 as small, a firm employing between 31-100 as medium and a firm employing more than 100 workers as large enterprise [21].

In contrast, the National Board for Small Scale Industries (NBSSI) in Ghana used both fixed assets and number of employees to define what constitutes SME in Ghana. It defined SME as a firm with not more than 9 workers, and has plant and machinery (excluding land, buildings and vehicles) not exceeding 10 million Ghanaian cedis. The definition by NBSSI has some challenges. The process of valuing fixed assets in Ghana poses a problem as well as the continuous fluctuation of the local currency as against the major trading foreign currencies usually makes it difficult to apply it in real situations especially for international comparisons [10].

\subsection{Empirical Evidence}

The available literature has a lot of information about the role of SMEs to employment and job creation in both developed and developing economies including Ghana.

The research paper published by [22] provided early evidence that SMEs are the primary engines of job creation. His findings showed that 81.5 percent of all net new jobs in the United States during 1969-1976 were created by firms with 100 or fewer employees. Similarly, [23] conducted a study in Turkey among non-farm business with 20 -100 employees and concluded that, small firms (firms with employees between 20 and 100 employees) had higher mean job creation rates than larger firms.

Another study conducted by [4] showed that SMEs are the largest contributors to total job creation across developing 
countries and have the largest share of employment, accounting for 71 percent of jobs in the transitional economies. Not only do SMEs employ the largest number of people, they also generate most new jobs. Furthermore, [24] asserted that the promotion of the SME sector is a core element to foster employment, economic growth, and poverty alleviation. [25] also found out that SMEs largely contribute to employment and [26] as well as [27] stated that this contribution has been increasing particularly in developing countries. Furthermore, [28] highlighted that SMEs in developing countries represent approximately 45 percent of employment and approximately 33 percent of GDP. Similarly, [29] investigated small and medium-sized enterprises and concluded that SMEs offered a large share of jobs in industrialized countries.

Another important aspect is that, SMEs generate the technical innovation that is needed to move the economy. The SMEs have the skills, innovative ideas and can take risks of exploring or discovering potential opportunities that lead to job creation and subsequently provide employment. For instance, a study performed by [30], confirmed that SMEs play a unique, active and critical role in the process of innovation by investing in new areas, sharing and transferring of technology among themselves. According to [31], in Singapore for example, even though SMEs are not as significant in terms of numbers and employment, they are important because they provide a flexible, skilled production base that attracts larger multinational corporations (MNCs). Also, [29] noted that, SMEs play a vital role in promoting economic growth and creating employment, and they fueled social development in a constantly changing economic environment. SMEs are flexible and have significant capacity to adjust, encourage by low dimensions and rapid decision making.

The SME sector serves as a major employer in Ghanaian's economy. The sector employs larger percentage of the working population in both rural and urban communities in Ghana. The SME sector helps utilize resources such as undesirable raw materials that might not yield any substantial foreign earnings to the country and hence would be wasted. About 92 percent of all businesses in Ghana are micro, small, medium scale enterprises [21]. This makes the SMEs sector to be one of the most important sectors in the Ghanaian economy for fiscal policy makers and development partners to strengthen and to further enhance the untapped talents and resources in the sector for job creation and employment.

\subsection{Regional Differences in SMEs'Role to Employment}

The evidence from the mature market economies indicate that significant spatial differences exist in the extent to which SMEs contribute to employment growth and economic development. For example, in UK around 1980 and 1990, there were large regional variations about opening of new firms and job creation. According to [32] more jobs were created in London and South East part of UK than the surrounding regions. It was also indicated by [33] that regions that were more fertile and good for business were having higher rate of new jobs openings than those regions with less fertile business activities. It has been established that the SMEs in the rural areas in UK perform better than their counterparts in the urban centers in terms of providing employment and job opportunities [34, 35].

Besides, [36] were with the view that the differences in the new firm formation rate is due to the variations in economic development, occupational structures, entrepreneurial ability, cultural factors and differences in the factors influencing demand and supply of factors of production. For example, in Estonia around 1995, there were marked differences in SME development where Greater Tallinn accounted for 54 percent of all registered businesses but with only a total population of 29 percent [37].

[11] asserted that micro firms and SMEs are distributed across and within countries. The SMEs are sparsely distributed across regions and countries as a result are flexible in terms of locational decisions and growth. Due to this locational flexibility, the SMEs can be used to achieve industrial dispersal and regional balance in socio-economic development of countries. The sparsely distribution of the SMEs make the sector the most important sector for diversifying and industrializing the economies especially the rural communities.

\subsection{Challenges of SMEs in Ghana}

The SMEs in Ghana like others in the world have various challenges facing the sector. The most typical challenges facing SMEs in Ghana include constraints to credit facilities, lack of managerial knowledge and skills, regulatory and legal challenges, challenges of accessing international market, equipment and technical know-how as well as lack of proper administrative and records keeping procedures [19, 38]. These and other challenges facing the SMEs in Ghana are impeding the full growth and development of the SMEs' sector to fully play its crucial role in developing the Ghanaian economy especially in the areas of employment and job creation.

One of the major challenges of SMEs in Ghana is access to credit facilities [39, 40]. In practice, it has been observed in Ghana that, the SMEs mobilise their source of capital for their business operations and investment through personal savings, family inheritance, borrowing from friends and financial institutions. The quantity of financial resources that could be accessed from these sources is at times limited to generate the needed set-up processes, growth and expansion of the firms. Not only that the SMEs in Ghana have the problem of accessing limited quantity of financial resources, the process of acquiring these financial resources from these sources are extremely difficult to come by. For instance, the documentation process, collateral facilities, high interest rates, short time for repayment are some of the constraints the SME operators go through in accessing credit from some of the financial institutions including banks in Ghana [38].

The second most important challenge of the SMEs in Ghana is the low level of managerial and knowledge based application by the SME owners [10]. The diverse nature of 
the SMEs business in Ghana couple with low incomes and capital, limit the SME owners to employ competent staff with the required managerial skills and experience to manage the business for higher efficiency and productivity. The higher proportions of SME owners and operators in the nation have low levels of literacy and numeracy to understand, accept and apply new ways of doing business. This impacts negatively on the operations and investment motives of the SME owners [38].

Another crucial challenge confronting the SMEs in Ghana is regulatory and legal issues [8]. It seems SMEs like all other business entities; operate well in well-functioning regulatory and legal frameworks. The high cost including bureaucratic process of registering business and weak public intuitions do not work well for SMEs; set-up, operations, growth and expansion. For instance,[41] observed as cited by [8], that it takes 127 days to deal with licensing issues and there are 16 procedures involved in licensing a business in Ghana.

In addition, the SMEs in Ghana are constraint to competing with and or entering into the international market due to high unit cost, low quality of products, nonstandardization of products, poor packaging and inability to undertake pragmatic market research as compared to their counterpart in the advanced economies. The SMEs do not only have the problem of competing with the international market, they are faced with local level market constraints due to macroeconomic instability such as higher inputs prices, poor infrastructure and high rate of taxes [8, 42].

Furthermore, the SMEs' sector in Ghana is hampered with rapid development of modern ways of doing business. There are more new, simple and complex tools, systems, equipment and machines that are helping business today to strive faster and improve on output. Again, advancement in technology and the use of improved tools, machines and equipment helps business to develop more competitive edge over their competitors. In Ghana, most SMEs do not have the ability and the capacity to acquire, adapt and apply the needed new ways of doing business due to perhaps low levels of income, managerial capabilities, and owners' complacency [43-45].

\section{The Methods and Data Source}

\subsection{Methods}

The study used descriptive statistics study designed type and analysed the levels of employment generated by MSMEs in Ghana by adopting the methods employed by GSS (GSS is the Government of Ghana department that is responsible for production and dissemination of official statistics in Ghana) to collect data on Integrated Business Establishment Survey II (IBES II)[21]. The study adopted the sampling frame of GSS for the IBES II. This is because the data for this present study were extracted from IBES II, 2016 report to analyse the role of MSMEs to employment in Ghana. The IBES II survey sampled 3,102,917 persons from 31,152 non-household establishments. These non-household establishments were either engaged in economic activities or were non-profit institutions and cut across all sectors of the economy. The IBES II used questionnaire and trained interviewers to collect the data from the public. The present study adopted the definition of MSMEs used by GSS to conduct the IBES II Survey. According to the GSS a Micro firm is the one that has engaged 1 to 5 persons, Small firm is the one with 6 to 30 employees, Medium enterprise is the one with 31to 100 employees whilst Large enterprise is any business entity that employees more than 100 workers in Ghana. For the purpose of this study, the Micro enterprise was part of the total SMEs for better understanding and analysis.

\subsection{Data Source}

This present study used existing data from the IBES II 2016 report[21]. This data was generated, organised and disseminated by GSS. The data sets used for the study included the levels (percentage share) of employment generated by MSMEs, the size and the status of employment (temporary and permanent employment) across the administrative regions in Ghana. The Microsoft excel was used to capture the data and run the descriptive statistics for the study.

\section{Results and Discussions}

Table 1. The percentage share of employment in the regions by MSMEs.

\begin{tabular}{lllll}
\hline $\begin{array}{l}\text { Administrative } \\
\text { Region }\end{array}$ & $\begin{array}{l}\text { Micro- } \\
\text { Sized }\end{array}$ & $\begin{array}{l}\text { Small- } \\
\text { Sized }\end{array}$ & $\begin{array}{l}\text { Medium- } \\
\text { Sized }\end{array}$ & MSMEs \\
\hline Western & 34.0 & 29.2 & 12.9 & 76.1 \\
Central & 39.1 & 36.1 & 9.8 & 85.0 \\
Greater Accra & 23.0 & 21.4 & 15.6 & 60.0 \\
Volta & 41.5 & 35.8 & 9.4 & 86.7 \\
Eastern & 38.6 & 34.2 & 9.9 & 82.7 \\
Ashanti & 40.1 & 32.9 & 11.5 & 84.5 \\
Brong Ahafo & 37.1 & 36.4 & 10.6 & 84.1 \\
Northern & 42.1 & 38.9 & 7.9 & 88.9 \\
Upper East & 36.2 & 38.0 & 10.1 & 84.3 \\
Upper West & 41.9 & 36.6 & 9.6 & 88.1 \\
National & 37.36 & 33.95 & 10.73 & 82.04 \\
Average & & & & \\
\hline
\end{tabular}

Sourced: Authors Computation, 2018

Table 1, portrays that about 82.04 percent of employment in Ghana is offered by the MSMEs. This evident was supported by $[25,29]$ who concluded that SMEs largely contributed to employment in both developing and developed nations respectively. The study further revealed that there are differences in the employment situations in the Regions due to differences in the levels of economic development in the country. In the Northern, Upper West, Volta and Central regions of Ghana, MSMEs play a critical role in providing employment to about $89,88,87$ and 85 percent of the labour force respectively. These regions are less developed unlike the other regions in the country. This conclusion was in line with the study made by [11] that regions that are fertile for business operations were having higher rate of new jobs opening and employment generation than those regions with 
less fertile grounds for business. But the picture is different with respect to the Greater Accra Region (the region with the national capital). In this region, MSMEs contribution to employment is the lowest among the regions in the country (about 60 percent) perhaps based on the fact that must of the larger industries are in the national capital which have swallowed the effect of the MSMEs in the region.

Another important conclusion of the study is that the contributions of MSMEs to employment by size (share of workers employed by each of the constituents of MSMEs) are different among the constituents of the MSMEs. The national averages for the contribution of MSMEs are about 37, 34, and 11 percent for Micro sized, Small and Medium sized enterprises respectively. This means that Micro sized firms (with workers between 1 to 5) in Ghana are employing about 37 percent of the entire labour force in the country with marked differences across the regions. The most noted regions where Micro firms are providing crucial employment to the teeming population include Northern, Upper West, and Volta regions with 42 percent of labour employed in each of these regions.

Table 2. The percentage share of status of employment by MSMEs in the Regions.

\begin{tabular}{|c|c|c|c|c|c|c|c|c|}
\hline \multirow{3}{*}{ Administrative Region } & \multicolumn{4}{|c|}{ Temporary } & \multicolumn{4}{|c|}{ Permanent } \\
\hline & Micro & Small & Medium & MSMEs & Micro & Small & Medium & MSMEs \\
\hline & Sized & Sized & Sized & & Sized & Sized & Sized & \\
\hline Central & 42.00 & 30.61 & 7.33 & 79.94 & 38.43 & 37.34 & 10.41 & 86.18 \\
\hline Greater Accra & 34.38 & 27.65 & 10.27 & 72.30 & 21.75 & 20.71 & 16.16 & 58.62 \\
\hline Volta & 45.71 & 37.19 & 5.79 & 88.69 & 40.51 & 35.52 & 10.26 & 86.29 \\
\hline Ashanti & 47.30 & 35.60 & 8.09 & 90.99 & 38.64 & 32.36 & 12.21 & 83.21 \\
\hline Brong Ahafo & 41.29 & 38.27 & 8.03 & 87.59 & 35.99 & 35.94 & 11.27 & 83.20 \\
\hline Northern & 38.52 & 47.94 & 5.65 & 92.12 & 43.28 & 35.97 & 8.61 & 87.86 \\
\hline Upper East & 40.32 & 44.61 & 5.58 & 90.51 & 34.83 & 35.68 & 11.71 & 82.23 \\
\hline Upper West & 41.97 & 43.04 & 7.16 & 92.18 & 41.85 & 34.42 & 10.43 & 86.70 \\
\hline National average & 41.67 & 36.57 & 7.32 & 85.57 & 36.49 & 33.20 & 11.56 & 81.24 \\
\hline
\end{tabular}

Sourced: Authors' Computation

From Table 2, about 86 percent of the employments offered by the MSMEs in Ghana are temporary whilst about 81 percent are permanent employment. The study revealed that there are marked differences in the status of employment across the regions in the country. In Greater Accra region for instance (where national capital is located) has the lowest rate (72 percent) of temporary employment whilst Northern and Upper West regions with common average of 92 percent are the regions with highest rate of temporary employment. Notwithstanding this, the Greater Accra region has the minimum rate (59 percent) of permanent employment as against the Northern region with 88 percent being the region with the highest rate of permanent employment offered by the MSMEs in the nation.

With respect to the status of MSMEs by size, the national averages for Micro sized enterprises and Small sized firms are about 42 and 37 percent for temporary employment respectively. In all, Micro and Small sized firms generate more temporary employment status as against permanent employment.

\section{Conclusions and Recommendations}

\subsection{Conclusions}

The study concluded that MSMEs are catalyst for generating employment and enhancing economic development in Ghana. It was also observed from the study that the role of MSMEs to employment creation is area specific. The differences in the characteristics of each of the regions in Ghana play a pivotal role in shaping the extent of the MSMEs' role in creating jobs and employment in general. The regions in Ghana that are well developed such as Greater Accra region do not have much impact of the role of MSMEs in providing employment because of the greater effect of larger enterprises. It was further revealed that the employment offered by the MSMEs in Ghana is mostly on temporary basis (about 86 percent) as against permanent employment (about 81 percent). The size of the MSMEs (measured by number of workers employed) is inversely related to the number of workers the enterprise can employed. This showed that Micro firms in all, employed more workers, and followed by Small firms and Medium firms. As the firm is growing in size, the total number of these firms becomes smaller thereby employing fewer workers in aggregate. It is concluding that the MSMEs in Ghana are generating more employment than that of the larger enterprises in aggregate.

In spite of this crucial role of MSMEs in providing employment in every corner in the economy of Ghana in other to reduce the teeming rate of unemployment and its associated challenges, the sector is confronted with various challenges such as:

1. Lack of access to credit

2. Lack of managerial skills

3. Regulatory and legal issues

4. Poor access to international market

5. Low level of applications of technical know-how and 
6. Lack of efficient administration and records keeping procedures

\subsection{Recommendations}

The MSMEs in Ghana are playing critical role in providing employment to the teeming working population throughout every corner in the economy. As a result, the study is recommending that:

1. The central, regional and district structures of the Government including development partners should put pragmatic structures in place to nurture and groom infant and emerging MSMEs as well as the existing ones in Ghana to develop and employ more of the unemployed population.

2. The Government of Ghana and her development partners should develop fiscal and monetary policies to resolve some of the teething challenges such as difficulty of accessing funding, poor record keeping, business registration and regulatory issues of the MSMEs sector. The Government should develop funding opportunities and advisory services to the emerging and existing enterprises of MSMEs to make the sector attractive to the youth.

3. The MSMEs in Ghana are located in every corner in the country. It means that there is the need for regional and district specific programmes, initiatives and fiscal policies to be formulated and developed to meet specific needs of the MSMEs. For example, tax and regulatory policies on MSMEs should be regional and district specific to take care of local level strength, weakness, threat and opportunities of the regional and district economies.

4. The key stakeholders in the MSMEs sector at all levels should be well resourced, restructured and monitored to work hand in hand with the MSMEs to enhance the growth of the sector so that MSMEs can offer more employment to the working population in the country. The public and private institutions in the country responsible for the development and promotion of the MSMEs sector throughout the country should be proactive. For instance, the Ministry of Trade and Industry of Ghana, National Board for Small Scale Industries, Ghana (NBSSI), and Association of Ghana Industries and the District Assemblies among others should be very resourceful to develop and assist in growing the MSMEs sector.

5. And finally, there should be training hubs or mentorship centers in and around the regions, districts and communities to groom, train and mentor the local entrepreneurs in modern ways of doing business including skills transfer, technology applications, information sharing and record keeping procedures to enable the MSMEs to expand their businesses and create more jobs for the teeming unemployed working population in the country.

\section{References}

[1] W. Nickell, The CEP-OECD institutions data set (1960-2004): Centre for Economic Performance, London School of Economics and Political Science, 2006.

[2] P. Stein, T. Goland, and R. Schiff, "Two trillion and counting: Assessing the credit gap for micro, small, and medium-size enterprises in the developing world," McKinsey \& Company and IFC, 2010.

[3] R. Kumar, "Targeted SME Financing and Employment Effects: What Do We Know and What Can We Do Differently?," World Bank, 2017.

[4] M. Ayyagari, A. Demirguc-Kunt, and V. Maksimovic, Small vs. young firms across the world: contribution to employment, job creation, and growth: The World Bank, 2011.

[5] J. Page, and M. Söderbom, "Is small beautiful? Small enterprise, aid and employment in Africa," African Development Review, vol. 27, no. S1, pp. 44-55, 2015.

[6] Y. Li, and M. Rama, "Firm dynamics, productivity growth, and job creation in developing countries: The role of microand small enterprises," The World Bank Research Observer, vol. 30, no. 1, pp. 3-38, 2015.

[7] H. C. Fang, R. V. Randolph, E. Memili et al., "Does size matter? The moderating effects of firm size on the employment of nonfamily managers in privately held family SMEs," Entrepreneurship Theory and Practice, vol. 40, no. 5, pp. 1017-1039, 2016.

[8] J. Abor, and P. Quartey, "Issues in SME development in Ghana and South Africa," International Research Journal of Finance and Economics, vol. 39, no. 6, pp. 215-228, 2010.

[9] E. Avevor, "Challenges faced by SMEs when accessing fund from financial institutions in Ghana," 2016.

[10] D. Kayanula, and P. Quartey, "Paper on the Policy Environment for Prompting Small and Medium-Sized Enterprise in Ghana and Malawi," University of Manchester: Crawford House, 2000.

[11] M. Oppong, A. Owiredu, and R. Q. Churchill, "Micro and small scale enterprises development in Ghana," European Journal of Accounting Auditing and Finance Research, vol. 2, no. 6 , pp. 84-97, 2014.

[12] K. Dalitso, and Q. Peter, "The policy environment for promoting small and medium-sized enterprises in Ghana and Malawi," University of Manchester, 2000.

[13] P. G. Piperopoulos, Entrepreneurship, innovation and business clusters: Routledge, 2016.

[14] M. Hosseini, S. Banihashemi, N. Chileshe et al., "BIM adoption within Australian Small and Medium-sized Enterprises (SMEs): an innovation diffusion model," Construction Economics and Building, vol. 16, no. 3, pp. 71, 2016.

[15] M. Hossain, and I. Kauranen, "Open innovation in SMEs: a systematic literature review," Journal of Strategy and Management, vol. 9, no. 1, pp. 58-73, 2016.

[16] M. S. Dar, S. Ahmed, and A. Raziq, "Small and medium-size enterprises in Pakistan: Definition and critical issues," Pakistan Business Review, vol. 19, no. 1, pp. 46-70, 2017. 
[17] Q. Hu, R. Mason, S. J. Williams et al., "Lean implementation within SMEs: a literature review," Journal of Manufacturing Technology Management, vol. 26, no. 7, pp. 980-1012, 2015.

[18] D. Perera, and P. Chand, "Issues in the adoption of international financial reporting standards (IFRS) for small and medium-sized enterprises (SMES)," Advances in accounting, vol. 31, no. 1, pp. 165-178, 2015.

[19] W. F. Steel, and L. M. Webster, How small enterprises in Ghana have responded to adjustment: The World Bank, 1991.

[20] B. Osei, A. Baah-Nuakoh, K. Tutu et al., "Impact of structural adjustment on small-scale enterprises in Ghana," Small Enterprises and Changing Policies: Structural Adjustment, Financial Policy and Assistance Programmes in Africa, IT Publications, London, 1993.

[21] GSS, Integrated Business Establishment Survey, Regional Spatial Business Report, Ghana Statistical Service, Accra, Ghana, 2016.

[22] D. L. Birch, "The Job Generation Process, Final Report to Economic Development Administration, Cambridge," $M A$ Program on Neighborhood and Regional Change Google Scholar, 1979.

[23] E. Dogan, M. Q. Islam, and M. Yazici, "Firm size and job creation: evidence from Turkey," Economic researchEkonomska istraživanja, vol. 30, no. 1, pp. 349-367, 2017.

[24] M. Ayyagari, A. Demirguc-Kunt, and V. Maksimovic, Firm innovation in emerging markets: The roles of governance and finance: The World Bank, 2007.

[25] T. Beck, A. Demirguc-Kunt, and R. Levine, "SMEs, growth, and poverty: cross-country evidence," Journal of economic growth, vol. 10, no. 3, pp. 199-229, 2005.

[26] C. E. Liedholm, and D. C. Mead, Small enterprises and economic development: the dynamics of micro and small enterprises: Routledge, 2013.

[27] M. Peden, R. Scurfield, D. Sleet et al., "World report on road traffic injury prevention," World Health Organization Geneva, 2004.

[28] P. Stein, T. Goland, and R. Schiff, "Two trillion and counting," International Finance Corporation and McKinsey \& Company, 2010.

[29] A. B. Bouazza, "Small and medium enterprises as an effective sector for economic development and employment creation in Algeria," International Journal of Economics, Commerce and Management, vol. 3, no. 2, pp. 1-16, 2015.

[30] A. De Massis, F. Frattini, J. Kotlar et al., "Innovation through tradition: Lessons from innovative family businesses and directions for future research," Academy of management Perspectives, vol. 30, no. 1, pp. 93-116, 2016.

[31] A. S. Saleh, P. Caputi, and C. Harvie, "Perceptions of business challenges facing Malaysian SMEs: some preliminary results," 2008.

[32] D. Keeble, and S. Walker, "New firms, small firms and dead firms: spatial patterns and determinants in the United Kingdom,” Regional studies, vol. 28, no. 4, pp. 411-427, 1994.

[33] P. Reynolds, D. J. Storey, and P. Westhead, "Cross-national comparisons of the variation in new firm formation rates," Regional studies, vol. 28, no. 4, pp. 443-456, 1994.

[34] D. Keeble, P. Tyler, G. Broom et al., Business success in the countryside: the performance of rural enterprise: HMSO, 1992.

[35] D. Smallbone, R. Leig, and D. North, "The characteristics and strategies of high growth SMEs," International Journal of Entrepreneurial Behavior \& Research, vol. 1, no. 3, pp. 44-62, 1995.

[36] G. J. Mason, "Stereotypies and suffering," Behavioural Processes, vol. 25, no. 2-3, pp. 103-115, 1991.

[37] D. Smallbone, D. North, and C. Kalantaridis, Growth and survival of small rural manufacturing firms: [np], 1997.

[38] E. Aryeetey, A. Baah-Nuakoh, T. Duggleby et al., Supply and demand for finance of small enterprises in Ghana: The World Bank, 1994.

[39] Y. Wang, "What are the biggest obstacles to growth of SMEs in developing countries?-An empirical evidence from an enterprise survey," Borsa Istanbul Review, vol. 16, no. 3, pp. 167-176, 2016.

[40] H. M. Osano, and H. Languitone, "Factors influencing access to finance by SMEs in Mozambique: case of SMEs in Maputo central business district," Journal of Innovation and Entrepreneurship, vol. 5, no. 1, pp. 13, 2016.

[41] B. Mundial, Doing business 2013: smarter regulations for small and medium-size enterprises: The World Bank, 2013.

[42] N. R. M. Sallem, N. E. M. Nasir, W. Nori et al., "Small and medium enterprises: Critical problems and possible solutions," International Business Management, vol. 11, no. 1, pp. 47-52, 2017.

[43] H. Musa, and M. Chinniah, "Malaysian SMEs Development: Future and Challenges on Going Green," Procedia-Social and Behavioral Sciences, vol. 224, pp. 254-262, 2016.

[44] O. Olayinka, M. G. Wynn, and K. Bechkoum, "E-business Adoption in Nigerian Small Business Enterprises," International Journal On Advances in Systems and Measurements, vol. 9, no. 3/4, pp. 230-241, 2016.

[45] P. Pillay, "Barriers to information and communication technology (ICT) adoption and use amongst SMEs: a study of the South African manufacturing sector," 2016. 